\title{
NO FUNDO, PROTESTOS ENVOLVEM QUESTÕES ORÇAMENTÁRIAS
}

Coluna publicada em 2.7.2013: <http://www.conjur.com.br/2013-jul-02/ contas-vista-fundo-protestos-envolvem-questoes-orcamentarias $>$

Já se completou um ano que esta coluna divulga as questôes relevantes no âmbito do Direito Financeiro, e procuramos trazer ao público um pouco mais de informação, em linguagem simples e acessível, sobre esse "tema que teima” em ser ainda desconhecido e aparentemente árido, não obstante sua enorme relevância no dia a dia de todos nós.

Não poderia haver melhor oportunidade para demonstrar essa importância do que analisar as manifestações que tomaram conta do país nos últimos dias. Isso porque elas envolvem, em sua gênese, uma questão essencialmente orçamentária.

Redução nos preços das passagens de ônibus, ou mesmo o "passe livre", nada mais é do que uma decisão que reflete uma escolha da sociedade sobre o que pretende do Estado enquanto ente responsável pelo financiamento e implementação das inúmeras políticas públicas que vão satisfazer as necessidades de todos.

"A decisão de gastar é fundamentalmente uma decisão política", já nos disse Regis de Oliveira, ${ }^{1}$ devendo os governantes ouvir e fazer respeitar a vontade da sociedade, a quem cabe decidir sobre a aplicação do dinheiro público.

Daí porque a especial atenção que se deve dar a dois aspectos sobre os quais o Direito Financeiro já se volta há muito tempo e cada vez mais se tornam relevantes: democracia e transparência.

Democracia para fazer com que os instrumentos voltados a melhor ouvir a população sejam efetivamente implementados, de modo a tornar as leis orçamentárias

1 OLIVEIRA, Regis Fernandes. Curso de direito financeiro. 4. ed. São Paulo: RT, 2011, p. 292. 
o reflexo exato daquilo que a sociedade espera que o poder público faça com o dinheiro que é dela.

Transparência para que todos possam tomar decisões conscientes e adequadas, sabendo exatamente o que foi, é e será feito com o dinheiro público, e da melhor forma. Mais do que isso: como, quando, e por quem será feito.

Todos esses e tantos outros são aspectos que compõem uma decisão nada simples, que deve ser tomada de forma democrática, consciente e transparente - como disse há poucos dias José Marcos Domingues de Oliveira, do que precisamos é de um orçamento sério, transparente e democrático (É necessário orçamento sério e prestação de contas, publicada no ConJur dia 21 de junho de 2013).

É fato que o orçamento é uma lei complexa, contendo informações jurídicas, econômicas, contábeis e administrativas, acessíveis a poucos. Em um país organizado na forma federativa, com clara separação de poderes, a dificuldade se torna ainda maior, tornando necessária a compatibilização de políticas públicas de interesse nacional, que envolvem, no mais das vezes, diversos entes da federação, com a necessidade de participação de vários poderes, tendo que se respeitar a autonomia de todos eles, que devem agir em cooperação, mitigando e superando seus interesses próprios em prol do bem comum.

Mesmo em questões como o transporte coletivo, atribuição do município (CF, art. 30, V), sob o comando do Poder Executivo, em que essas dificuldades podem parecer menores, por não envolver diretamente outros poderes e entes federados, muitas decisões há que se tomar. Regimes de contratação, formas de remuneração, coordenação com outros sistemas de transporte gerenciados por outras unidades da federação e tantos outros aspectos mostram que a administração pública não é tarefa simples.

Também não é fácil saber precisamente o que a população pretende nos inúmeros programas que compõem o orçamento público. "Encargos Gerais", "Participação Societária", "Suporte Administrativo", "Política Externa”, "Resíduos Sólidos", "Controle Externo", "Biodiversidade" são apenas exemplos de denominações de alguns programas entre as centenas que compõem os orçamentos da União, estados e municípios. Vê-se a difícil tarefa que é traduzir os anseios populares nas descrições de programas e respectivas ações, indicadores, metas e resultados que vão compor o orçamento público.

Há instrumentos para isso. Orçamentos participativos, audiências públicas e tantas outras técnicas previstas na legislação tornam mais democrática a elaboração do orçamento. E a evolução cada vez mais intensa da transparência fiscal permite às pessoas conhecer detalhes sobre o gasto público, tornando-as mais conscientes $\mathrm{e}$ 
responsáveis com o dinheiro público e capazes de colaborar mais e melhor na elaboração e fiscalização da lei orçamentária.

Ouvir o povo e representá-lo. Para isso existem os políticos. Eleitos são, e a sociedade lhes paga cara estrutura, com assessores, técnicos, órgãos e toda uma dispendiosa máquina estatal para que, justamente, traduzam a voz das ruas na lei orçamentária, que deve expressar da forma mais fiel possível a destinação desejada para os recursos públicos. Para isso pedem votos com os quais serão eleitos, sendo o momento mais importante do exercício do mandato recebido justamente a elaboração e aprovação da lei orçamentária, quando se define a destinação do dinheiro público.

Momento de decisões fundamentais e importantes. E difíceis. Decisões que podem importar em "escolhas trágicas", aproveitando do sugestivo título da obra de Guido Calabresi e Philip Bobbit. ${ }^{2}$ Ou "trágico-políticas", como também coloca com propriedade Fernando Scaff neste mesmo espaço (Reserva do possivel pressupõe escolhas trágicas, publicada no ConJur em 26 de fevereiro de 2013).

Será mesmo? Talvez.

Talvez sim porque, como se ouviu de declarações de vários governantes nesse período, o passe livre, ou a redução no valor das passagens, vai importar em diminuição dos investimentos em saúde, educação e outros de suma relevância - caso que, efetivamente, seria uma escolha efetivamente "trágica": ônibus grátis versus menos vagas em hospitais é um dilema que ninguém gostaria de ser obrigado a decidir.

Talvez não porque, como já mencionei em coluna anterior (Não falta dinheiro à administração pública, falta gestão, nesta edição, p. 255-258), há muito dinheiro sendo desperdiçado sem nenhuma contrapartida útil à sociedade, em valores que, se apurados, impressionariam pelo montante. E que, sem necessidade de muitos cálculos, permitiriam constatar que a verdadeira escolha seja "ônibus grátis versus administração deficiente”, que não é nem um pouco trágica, muito menos difícil de ser tomada. Mas que, curiosamente, tem se mostrado difícil de ser implementada, e sem uma explicação plausível, pois não se consegue compreender a quem interessa a má administração, em que todos saem perdendo.

As "escolhas trágicas" só se mostrarão presentes e necessárias se e quando a administração pública estiver trabalhando em perfeita sintonia entre os poderes, órgãos públicos e entes federados, com uso das mais modernas técnicas de gestão,

2 Tragic Choices. The conflicts society confronts in the allocation of tragically scarce resources. New York: W. W. Norton \& Company, 1978. 
sem desperdício de recursos públicos. Aí sim, poder-se-ia admitir que os recursos estão limitados e o aumento ou destinação para uma finalidade importará em redução ou exclusão de outra despesa.

Não parece ser o caso, não tenho dúvida de que estamos longe disso. Seguramente é possível ter ônibus grátis, ou atender a muitas outras reivindicações (e vê-se que não faltam...) sem grandes sacrifícios ou "escolhas trágicas".

O fato é que, do que se pode ver nas ruas, uma conclusão é certa: os políticos não estão fazendo bem o seu trabalho.

Falham os que ocupam cargos no Poder Executivo, por não serem bons gestores, mostrando-se incapazes de tornar a administração pública uma máquina moderna e eficiente.

Falham os que integram o Poder Legislativo, por não estarem traduzindo a vontade da população na definição dos gastos públicos que tem dado demonstraçôes de que prefere ônibus grátis a estádios para a Copa do Mundo.

O povo brasileiro tem mostrado nos últimos dias insatisfação com seus políticos e deixando-lhes um recado bastante claro: querem ser ouvidos e ter sua voz bem traduzida e respeitada. Devem eles, mais do que nunca, dar maior atenção à lei orçamentária e ao trato com o dinheiro público, pois o povo está mostrando do que é capaz. 